\title{
The buffering capacity of porcine muscles
}

\author{
Kylä-Puhju, Maria
}

Elsevier

2004

Meat Science. 2004. 67(4): 587-593.

http://hdl.handle.net/1975/689

http://dx.doi.org/10.1016/j.meatsci.2004.01.001

Downloaded from Helda, University of Helsinki institutional repository.

This is an electronic reprint of the original article.

This reprint may differ from the original in pagination and typographic detail.

Please cite the original version. 


\section{THE BUFFERING CAPACITY OF PORCINE MUSCLES}

Maria Kylä-Puhju $^{1 *}$, Marita Ruusunen ${ }^{1}$, Riitta Kivikari ${ }^{2}$, Eero Puolanne ${ }^{1}$

1 Department of Food Technology, University of Helsinki, PO Box 27, Helsinki, Finland 2 Department of Applied Chemistry and Microbiology/Food Chemistry, University of Helsinki, PO Box 27, Helsinki, Finland

Correspondence to: Maria Kylä-Puhju

University of Helsinki

Department of Food Technology

PO Box 27 (Viikki E)

FIN-00014 Helsinki

FINLAND

Tel: $\quad$ +3589 $\quad$ +

Fax: $\quad$ +3589 19158460

E-mail address: $\quad$ maria.kyla-puhju@helsinki.fi

\section{Abstract}

The aim of this study was to investigate the buffering capacity (BC) of five porcine muscles. The $\mathrm{pH}$ of muscles with zero lactate was also estimated. The BC was calculated on the basis of the amount of lactate accumulating in the muscle between two sampling times and the simultaneous $\mathrm{pH}$ decline. Two muscle samples were obtained from each muscle $(\mathrm{n}=13-36)$ :

${ }^{*}$ Corresponding author

Kylä-Puhju et al. (2004). The buffering capacity of porcine muscles. Meat Science, 67, 587-593. 
one as soon as possible after slaughter and the other $24 \mathrm{~h}$ post-mortem. The BCs (mmol lactate/(pH*kg)) were in the light gluteus superficialis, longissimus dorsi and semimembranosus muscles $48.3 \pm 8.8,48.6 \pm 9.2$ and $46.8 \pm 13.0$, and in the dark infraspinatus and masseter muscles $45.3 \pm 13.1$ and $32.0 \pm 11.5$, respectively. The dark masseter muscle differed significantly from the other muscles studied $(\mathrm{p}<0.01)$. The estimated $\mathrm{pH}$ values of muscles with zero lactate were in the gluteus, longissimus dorsi, semimembranosus muscles $7.14 \pm 0.06$; 7.18 $\pm 0.06 ; 7.38 \pm 0.08$, and in the infraspinatus and masseter muscles $6.87 \pm 0.07$; $7.03 \pm 0.08$, respectively. It was suggested since lactate is continuously formed in the muscles, the resting $\mathrm{pH}$ of living light and dark muscles may, however, be the same. The approach used in this study to determine the BC resulted in values which are close to values previously reported in the literature (measured by using titration curves).

Keywords: Muscle; Pig; Buffering capacity; pH

\section{Introduction}

The chain of events that leads to the conversion of muscle to meat is complex, and it involves a series of biochemical reactions in the muscle fibre, resulting in conformational changes in the myofibrillar system. As a result of post-mortem metabolism, glycogen and ATP levels decline, and lactic acid accumulates in the muscle. This lowers the muscle $\mathrm{pH}$ (Kastenschmidt, Hoekstra \& Briskey, 1968) and results in an ultimate pH of about 5.4 to 5.7 at $24 \mathrm{~h}$ in porcine longissimus dorsi muscle (Briskey \& Wismer-Pedersen, 1961). The amount of glycogen present in the muscle will determine the extent of the $\mathrm{pH}$ decrease, but only if the glycogen concentration in pig muscles has decreased to values below $53 \mathrm{mmol} / \mathrm{kg}$ wet weight in the living animal (Henckel, Karlsson, Jensen, Oksbjerg, \& Petersen, 2002). The pH has a 
direct or indirect influence on several characteristics of meat, such as colour, water-holding capacity, tenderness, juiciness and flavour (Kauffman et al., 1993). The effects of pH on meat quality have been thoroughly reviewed e.g. by Hamm (1972), Bendall \& Swatland (1988) and Offer \& Knight (1988).

The fall in $\mathrm{pH}$ during the post-mortem reaction sequence is a function of both the amount of acid formed and of the buffering capacity (BC) of muscle (Bate-Smith, 1938; Kivikari, 1996, review). In chicken pectoralis (van Laack, van Liu, Smith \& Loveday, 2000) and in pork longissimus dorsi (van Laack \& Kauffman, 1999), muscles with equal lactate content may have different ultimate $\mathrm{pH}$ values. This may be explained by differences in buffering capacity (van Laack, Kauffman \& Greaser, 2001).

Buffering capacity is the ability of meat to resist the change in $\mathrm{pH}$ when acid or alkali is added. Usually the buffering capacity of meat is measured using titration curves (Kivikari, 1996, review). The measure for the buffering capacity, $\beta$, is the slope of the titration curve ( $\mathrm{pH}$ plotted against increments of alkali or acid) at any point; $\beta=\delta \mathrm{A} / \delta \mathrm{pH}, \delta \mathrm{A}=$ the amount of added acid/alkali, $\delta \mathrm{pH}=$ the corresponding change of $\mathrm{pH}$.

The value of $\mathrm{K}_{\mathrm{a}}$ for lactic acid is $1.38 * 10^{-4}$. Theoretically, adding lactic acid (10 mmol) to pure water $\left(1 \mathrm{dm}^{3}\right)$ causes the $\mathrm{pH}$ to fall from 7.00 to 2.93 . The buffering capacity of muscles balances the $\mathrm{pH}$ change and prevents the rapid $\mathrm{pH}$ decrease followed by rapid glycolysis. Buffering capacity is an important property of both living muscle and post-mortem meat. The same chemical compounds that regulate $\mathrm{pH}$ in a living muscle fibre also regulate it postmortem (Kivikari, 1996, review). 
Several values (which differ from each other according to the dilution ratio used in titrations) have been presented for the BC of porcine muscles: for psoas $57 \mathrm{mmol} \mathrm{H}^{+} / \mathrm{pH}^{*} \mathrm{~kg}(\mathrm{pH} 6-7)$ (Bate-Smith, 1938), for longissimus dorsi 55 mmol H$/ \mathrm{pH}^{*} \mathrm{~kg}$ (pH 5.2-6.5) (Sayre, Briskey \& Hoekstra, 1963), 57 mmol H$/ \mathrm{pH}^{*} \mathrm{~kg}$ (pH 5.2-6.5) (Monin \& Sellier, 1985), 60-64 mmol $\mathrm{H}^{+} / \mathrm{pH}^{*} \mathrm{~kg}$ (pH 6-7) (Henckel, Jörgensen, \& Jensen, 1992), 52 mmol H$/ \mathrm{pH}^{*} \mathrm{~kg}$ (pH 5.5-7.0) (Puolanne \& Kivikari, 2000), for adductor 50 mmol H$/ \mathrm{pH}^{*} \mathrm{~kg}$ (pH 6-7) (Castellini \& Somero, 1981) and for triceps brachii 45 mmol H$/ \mathrm{pH}^{*} \mathrm{~kg}$ (pH 5.5-7.0) (Puolanne \& Kivikari, 2000).

Buffering capacity is a function of $\mathrm{pH}$. The most influential compounds in the $\mathrm{pH}$ range of 5.5-7.0 are phosphate compounds having $\mathrm{pK}_{\mathrm{a}}$ values between 6.1 and 7.1, the dipeptides carnosine and anserine, and histidylimidazole residues of myofibrillar proteins (Kivikari, 1996, review). Myofibrillar proteins are responsible for approximately half of the buffering capacity of meat in the pH range 5.5-7.0 (Honikel \& Hamm, 1974). Different phosphate compounds have different $\mathrm{pK}_{\mathrm{a}}$ values, and during the post-mortem reaction sequence, the buffering capacity of each compound changes, depending on how its $\mathrm{pK}_{\mathrm{a}}$ value is related to the $\mathrm{pH}$ value of meat (Kivikari, 1996, review). As a result, there are minor differences in pre rigor and rigor buffering capacities. According to Kivikari (1996) the difference in BC during the post-mortem reaction sequence is approximately $8 \mathrm{mmol} \mathrm{H}^{+} /\left(\mathrm{pH}^{*} \mathrm{~kg}\right)$ at the maximum point of the curve. This is caused mostly by free phosphate ions.

Puolanne \& Kivikari (2000) found that the dilution ratio affects the BC curves determined by titration. With a dilution ratio of 10/100 they found a maximum buffering capacity of $65.4 \mathrm{mmol} \mathrm{H} / \mathrm{pH}^{*} \mathrm{~kg}$ at $\mathrm{pH} 6.65$ and a minimum of $38.9 \mathrm{mmol} \mathrm{H}^{+} / \mathrm{pH}^{*} \mathrm{~kg}$ at $\mathrm{pH} 5.56$ for porcine longissimus dorsi muscle. The equivalent BCs with a dilution ratio of 10/10 were $57.2 \mathrm{mmol} \mathrm{H}^{+} / \mathrm{pH}^{*} \mathrm{~kg}$ at $\mathrm{pH} 6.69$ and $48.9 \mathrm{mmol} \mathrm{H}^{+} / \mathrm{pH}^{*} \mathrm{~kg}$ at $\mathrm{pH} 5.70$, respectively. They 
assumed that the less water used in the determination of the BC curve, the more the curve takes on a shape with no separate maximum or minimum. According to Puolanne \& Kivikari (2000) the most probable consequence of this is that when no added water is used in the titration, the buffering capacity is constant in a pH range of approximately 5.8-6.5. The BC has also been determined without dilution (e.g. Bendall, 1973; Bendall, 1979; Talmant, Monin, Briand, Dadet \& Briand, 1986; Guignot, Quilichini, Renerre, Lacourt \& Monin, 1992), but information on the BC of intact post-mortem meat is insufficient.

Muscles can be classified into dark and light types, which differ on the basis of their fibre composition. Most muscles have a fibre composition which is a mixture of light and dark fibres. The BC is found to be higher in light anaerobic muscles than in dark ones (Davey, 1960; Rao \& Gault, 1989; Okuma \& Abe, 1992; Kivikari, 1996). In living muscles, dark fibres tend to maintain their energy-rich phosphate levels aerobically, but light fibres have a stronger aptitude to maintain their ATP supply anaerobically, and the formation of lactic acid (Fernandez, Tornberg, Naveau, Talmant \& Monin 1992; Henckel et al., 2002) tends to lower the $\mathrm{pH}$ value in the fibre (Olsman \& Slump, 1981). Many of the treatments which living animals are exposed to have a strong impact on muscle metabolism and, therefore, the measuring of the $\mathrm{pH}$ value of living muscle is difficult (Roos \& Boron, review 1981). The situation where there is zero lactate in muscle, may offer valuable information about differences between muscles.

Somero (1986) states that a high buffering capacity in muscle stabilises intramuscular $\mathrm{pH}$ and enhances the capability for anaerobic metabolism. Differences in the BC of the various muscle types can be explained by variations in dipeptide, mainly carnosine, anserine (Kivikari, 1996, review) and balenine ( $\beta$-alanyl-3-methyl-histidine) contents (Olsman \& Slump, 1981). 
The aim of this study was to examine the actual (i.e. without any dilution) buffering capacity of porcine muscles post-mortem. In this study, the BC was calculated on the basis of lactate accumulation in the muscle, in relation to the change in $\mathrm{pH}$ value during $24 \mathrm{~h}$ after slaughter. The $\mathrm{pH}$ values of muscles with zero lactate were also estimated.

\section{Materials and methods}

\subsection{Animals and sampling}

Muscles of Finnish Landrace and Large White pigs and their crosses were used. The pigs were slaughtered at the age of $165 \pm 2$ days. The live weight of the pigs ranged from 86.0 to $118.5 \mathrm{~kg}$. On the day of slaughter, the pigs were transported (approximately $1 \mathrm{~h}$ ), two at a time, to a pilot abattoir. They were allowed to rest for $2 \mathrm{~h}$ before slaughter and then stunned electrically.

Samples were taken from light gluteus superficialis (25-30 min pm), longissimus dorsi (1518 min pm), and semimembranosus (about 40 min pm) muscles and from dark infraspinatus (15-18 min pm) and masseter (15-18 min pm) muscles. The numbers in parentheses indicate sampling time 1 (ST1) after the stunning. The number of muscle samples varied between 13 and 36 (see Table 1). The next samples were taken $24 \mathrm{~h}$ post-mortem (ST2). The elapsed time between the sampling times was long because the animals were also used in a different study. The samples were cut into small pieces and frozen in liquid nitrogen. Freezing took place within 1 min after sampling. The samples were stored at $-80^{\circ} \mathrm{C}$ until they were used for the analyses. 


\subsection{Measurements}

The $\mathrm{pH}$ values were measured in meat extracts $(1 \mathrm{~g}$ muscle $+10 \mathrm{ml} 5 \mathrm{mM}$ Na-Iodoacetic acid solution) by using a Knick Portamess $752 \mathrm{pH}$-meter equipped with a Mettler-Toledo Inlab 427 electrode. Extracts were made from muscles which were frozen just after the sampling $\left(\mathrm{pH}_{\mathrm{ST} 1}\right)$, and from samples which were frozen $24 \mathrm{~h}$ post-mortem $\left(\mathrm{pH}_{\mathrm{ST} 2}\right)$. The frozen samples were homogenised in icy Na-Iodoacetic acid and the $\mathrm{pH}$ values were measured at room temperature.

For lactate determinations, muscle samples were homogenised in ice-cold $0.1 \mathrm{M}$ phosphate buffer ( $\mathrm{pH}$ 7.0) with a Polytron homogenizer. Lactate concentration was determined spectrophotometrically (365 nm) using a commercial kit (Boeringer-Mannheim no. 139 084).

The reproducibility of the lactate assays was determined as follows: a large muscle sample was ground in liquid nitrogen, divided into small pieces and stored at $-80{ }^{\circ} \mathrm{C}$. This sample was analysed every time the samples were analysed. The coefficient of variation (CV) was $\pm 12.5 \%$ for the lactate analyses.

The total pigment content was first analysed with Trout's (1991) method and the relative amount of myoglobin was determined electrophoretically by the Pharmacia separation technique (Phasta System ${ }^{\mathrm{TM}}$, 1989).

The buffering capacity of each muscle sample was calculated as described by Hill, Irvine and Bullock (1985), i.e. based on the amount of lactate accumulating in the muscle between the first and second sampling and the simultaneous $\mathrm{pH}$ decline: 
$\mathrm{BC}=\Delta \mathrm{A} / \Delta \mathrm{pH}$,

where $\Delta \mathrm{A}$ is the observed increase of lactate (mmol); and $\Delta \mathrm{pH}$ is the change in $\mathrm{pH}$ of muscle.

\subsection{Statistical analysis}

The statistical analysis was carried out with the Statistical Analysis System version 6.12 (SAS, 1990). The MIXED procedure was applied when calculating the least squares means of all the variables. The REG procedure was applied when the $\mathrm{pH}$ values of muscles with zero lactate were estimated.

\section{Results and discussion}

\subsection{Lactate production, $\mathrm{pH}$ value and the buffering capacity of the muscles}

The myoglobin contents (mg/g) were 5-6 times higher in the dark infraspinatus and masseter muscles (11.2 \pm 3.4 and 11.6 \pm 1.4 , respectively) than in the light gluteus, longissimus dorsi and semimembranosus muscles (2.6 $\pm 0.5,1.8 \pm 0.4$ and $2.2 \pm 0.6$, respectively). This is consistent with the results of Morita, Cassens, Briskey, Kauffman \& Kastenschmidt (1970) and Livingston \& Brown (1981), who found that dark muscles contain more myoglobin than light ones.

As compared with the dark muscles, the $\mathrm{pH}_{\mathrm{ST} 2}$ of the light muscles was significantly lower $(\mathrm{p}<0.001)$ and there was significantly more lactate at $24 \mathrm{~h}$ after slaughter $(\mathrm{p}<0.001)$ (Table 1$)$. Fernandez \& Tornberg (1991) have reported that the ultimate pH differs in different types of 
pig muscles, basically because light muscles contain more initial glycogen than dark muscles (Monin, Mejenes-Quijano \& Talmant, 1987). This was also the case in this study, although the results of glycogen content are not shown.

In the semimembranosus muscle the lactate content was higher and the glycogen content lower (Ruusunen \& Puolanne, 2003) than in the other light muscles studied (Table 1). This may be due to the differences in sampling time, since the sample from the semimembranosus was taken later than from the other muscles. Because of the differences in ST1, it is not reasonable to compare the $\mathrm{pH}$ and lactate values directly. The aim of this paper is to compare the ratio of lactate content and $\mathrm{pH}$ between different muscles. The differences in lactate content or pH at ST1 are not of importance as absolute values.

The $\mathrm{pH}_{\mathrm{ST1}}$ (Table 1) was different only between the semimembranosus and the masseter muscles. The fact that the $\mathrm{pH}_{\mathrm{ST1}}$ was not different for most muscles, despite differences in the lactate content at ST1, could be attributed to the higher buffering capacity of the light muscles, which has been shown earlier by Rao \& Gault (1989).

The average $\mathrm{BC}$ in the particular $\mathrm{pH}$ range (from $\mathrm{pH}_{\mathrm{ST} 1}$ to $\mathrm{pH}_{\mathrm{ST} 2}$ ) of each individual muscle sample was calculated on the basis of lactate accumulation in the muscle in relation to the simultaneous change in $\mathrm{pH}$ value. The means and standard deviations of these results are presented in Table 1. The BC was different in different muscles and the trend indicated a higher buffering capacity in the light muscles than in the dark ones. There was a significant $(\mathrm{p}<0.001)$ difference between the BCs of dark masseter muscle and the light muscles studied, but the BC of the infraspinatus muscle seemed to be at the same level as that of the light muscles. 
The buffering capacities of light muscles (Table 1) are at the same level as the mean BC value of Puolanne \& Kivikari (2000): $52 \mathrm{mmol} \mathrm{H}^{+} /\left(\mathrm{pH}^{*} \mathrm{~kg}\right)$ for porcine longissimus dorsi muscle (estimated from titrations made with dilution ratios of 1:10 and 1:1) when the $\mathrm{pH}$ range was from 5.5 to 7.0. The BC of the masseter muscle was lower than of that of the infraspinatus muscle and the same as (Table 1) the mean BC value of Puolanne \& Kivikari (2000) for porcine dark triceps brachii muscle: $45 \mathrm{mmol} \mathrm{H}^{+} /\left(\mathrm{pH}^{*} \mathrm{~kg}\right)$. Furthermore, Guignot et al. (1992) have determined the buffering capacity of three different veal muscles with titration and also with the method used in this study and obtained values which were very close to each other.

Buffering capacity remains constant over a certain $\mathrm{pH}$ range only if the titration curve over the same pH range is linear. Hamm (1977), however, has pointed out that a linear relationship between the linear magnitude of lactate concentration and the logarithmic magnitude of $\mathrm{pH}$ is by no means self-evident. However, in meat samples the correlation between lactic acid concentration and $\mathrm{pH}$ value can be considered as linear or almost linear because the $\mathrm{pH}$ lactate curve in the $\mathrm{pH}$ range 5.5-7 represents the almost linear medium part of the titration curve (Hamm, 1977). The $\mathrm{pH}$ values of muscles in this study were close to this range and BC could be considered constant. There are differences in pre rigor and rigor BC. As mentioned in the introduction, these are caused mostly by free phosphate ions, but the differences are small (Kivikari, 1996) and do not have a marked effect on the results. This is because at ST1 the number of free phosphate ions in the muscle has not increased markedly, and at ST2 they have only a marginal effect.

Puolanne \& Kivikari (2000) found that the dilution ratio affects the BC curves determined by titration. They assumed that the less water used in the determination of the BC curve, the more the curve has a shape with no separate maximum or minimum, and the most probable consequence of this is that when no added water is used in the titration, the buffering capacity 
is constant in a pH range of approximately 5.8-6.5. In this study the BCs were determined without dilution, and this approach resulted, as expected, in slightly lower values than presented earlier in the literature.

\subsection{The calculated $\mathrm{pH}$ of muscle with zero lactate}

The $\mathrm{pH}$ of muscle with zero lactate was extrapolated by fitting a linear regression model to the data obtained from ST1. In this study it was assumed that the BCs of the same muscle of each animal were approximately equivalent. The assumption was based on the fact that the animals were from the same genetic line, reared similarly and gave the $\mathrm{BC}$ results presented above. There were, however, some unexpectedly high differences in the data; sometimes the pH value showed large variations at the same lactate content (Figs. 1 (a)-(e)).

The extrapolated values of the $\mathrm{pH}$ of a muscle with zero lactate ( \pm standard error) in the light gluteus, longissimus dorsi and semimembranosus muscles were 7.14 $\pm 0.06(\mathrm{r}=0.88)$, $7.18 \pm 0.06(\mathrm{r}=0.90)$ and $7.38 \pm 0.08(\mathrm{r}=0.90)$ and in the dark infraspinatus and masseter muscles $6.87 \pm 0.07(\mathrm{r}=0.65)$ and $7.03 \pm 0.08(\mathrm{r}=0.73)$, respectively. The coefficients of correlation were not very good in the dark muscles, the possible result being a $\mathrm{pH}$ value that is slightly too low, especially in infraspinatus in a zero lactate situation. Nevertheless, the difference between the light and dark muscles remains, though the difference may be smaller. The low coefficients of correlation were probably due partly to the smaller range of variation in the lactate content and $\mathrm{pH}$ value of the dark muscles. Furthermore, dark muscles are not as homogeneous as the light muscles.

Also Renou, Canioni, Gatelier, Valin \& Cozzone (1986) extrapolated initial pH value (pH at the time of slaughter) by fitting a linear regression for rabbit psoas major muscle, and 
obtained a value of 7.14, which is in agreement with our results and also with Bendall's (1975) results for the initial $\mathrm{pH}$ values porcine semimembranosus, longissimus dorsi and gluteus medius muscle: 7.16, 7.16 and 7.24, respectively.

Kivikari (1996) estimated that the $\mathrm{pH}$ value of living muscles (M. longissimus dorsi, $\mathrm{M}$. triceps brachii) for pork and bovine is 7.2 and for broiler (breast muscles, leg-thigh muscles) 7.6, the latter being unexpectedly high. Our extrapolated results for light porcine muscles were in agreement with Kivikari’s (1996) results. In the dark muscles the $\mathrm{pH}$ was lower than in Kivikari’s study.

Fernandez et al. (1992) and Henckel et al. (2002) have studied the longissimus dorsi muscle of a resting pig using biopsy sampling, and found a lactate content of about 5 and $11 \mathrm{mmol} / \mathrm{kg}$ muscle wet weight, respectively. Sepponen, Koho, Puolanne, Ruusunen \& Pösö (2003) have speculated that because both the capillary and mitochondrial densities are low in porcine muscles, small amounts of lactate are continuously formed as a result of anaerobic glycolysis. Considering that there is always some lactate in the muscle, the resting $\mathrm{pH}$ of porcine longissimus dorsi muscle of a living animal in this study is about 6.95-7.07. Also, Tarrant, McLoughlin \& Harrington (1972) have measured an initial $\mathrm{pH}$ value of $7.0 \pm 0.03$ for living anaesthetised porcine longissimus dorsi muscle and assumed that this value was probably close to the $\mathrm{pH}$ of resting, normal muscle.

In muscle, the major portion of carrier-mediated lactate transport occurs via the function of monocarboxylate transporters (MCT), which transport a lactate anion and a proton together in the direction of a declining lactate gradient (Juel, review 1997). Sepponen et al. (2003) found that MCT2 along with MCT4 appear to be the major isoforms in both the dark and the light porcine muscles and that the amount of MCT2 is higher in light porcine muscles than in dark 
ones. Because light muscles are more glycolytic than dark ones (Briskey \& Wismer-Pedersen, 1961; Merkel, 1971; Lundström, Essén-Gustavsson, Rundgren, Edfors-Lilja \& Malmfors, 1989; Warner, Kauffman \& Russell, 1993), it can be assumed that there is already more lactic acid in living light muscle than in dark muscle. This would induce a problem because all muscles consist of light and dark muscle fibres, and an existence of a pH gradient between light and dark fibres would not be energetically favourable and would lead to ion exchange. Our finding that $\mathrm{pH}$ of light muscles with zero lactate is higher than that of dark muscles suggests that adjacent muscle fibres may have different energy metabolisms. Because in light muscles lactic acid is continuously formed more than it can be utilised [based on the resting lactate content found by Fernandez et al. (1992) and Henckel et al. (2002)], the lactic acid formed must be transported out of the fibres. Sepponen et al. (2003) suggest that in glycolytic porcine fibres, lactate concentration could be kept at a low level by the function of MCT2. The lactic acid is transported from light fibres to dark fibres, which have a higher capacity to use it for energy production (Juel, review 1997). Because of the difference in pH between light and dark muscle fibres with zero lactate, it would be possible to continuously produce lactic acid in light muscle fibres and transport it via interstitial space to dark muscle fibres without developing a disadvantageous $\mathrm{pH}$ gradient.

On the basis of the above information, we suggest that because there is more lactic acid in light muscle fibres than in dark ones, the $\mathrm{pH}$ with zero lactate must be higher in light fibres than in dark fibres to avoid the development of an energetically unfavourable $\mathrm{pH}$ gradient between these fibres. Consequently, the resting $\mathrm{pH}$ of living light and dark fibres can be the same. However, more research on the $\mathrm{pH}$ value of adjacent muscle cells is needed. 


\section{Conclusions}

This study points out that the buffering capacity calculated from the lactate accumulation and the simultaneous $\mathrm{pH}$ decrease in muscle, i.e. without dilution, gives results which are close to the values determined with the titration method and reported in the literature. The method is also rapid and easy to carry out. The buffering capacities are higher in light porcine muscles than in dark porcine masseter muscle. The estimated $\mathrm{pH}$ value of light muscles with zero lactate is higher than that of dark muscles. It was suggested that since lactate is continuously formed in the muscles, the resting $\mathrm{pH}$ of living light and dark muscles may, however, be the same.

\section{Acknowledgements}

This research was funded by the Ministry of Agriculture and Forestry and the Meat Board. We thank laboratory technician Irja Korhonen for her technical assistance with sampling and analyses. The critical comments of Professor Reeta Pösö were greatly appreciated.

\section{References}

Bate-Smith, E. C. (1938). The buffering of muscles in rigor; protein, phosphate and carnosine. Journal of Physiology, 92, 336-343.

Bendall, J. R. (1973). Postmortem changes in muscle. In G.H. Bourne, The structure and function of muscle, Volume II, Structure, part 2 (pp. 243-309). New York, Academic Press. 
Bendall, J. R. (1975). Cold-contracture and ATP-turnover in the red and white musclulature of the pig, post mortem. Journal of Science in Food and Agriculture, 26, 55-71.

Bendall, J. R. (1979). Relations between muscle pH and important biochemical parameters during the post-mortem changes in mammalian muscles. Meat Science, 3, 143-157.

Bendall, J. R. \& Swatland, H. J. (1988). A review of the relationships of pH with physical aspects of pork quality. Meat Science, 24, 85-126.

Briskey, E. J. \& Wismer-Pedersen, J. (1961). Biochemistry of pork muscle structure. I. Rate of anaerobic glycolysis and temperature change versus the apparent structure of muscle tissue. Journal of Food Science, 26, 297-305.

Castellini, M. A. \& Somero, G. N. (1981). Buffering capacity of vertebrate muscle: Correlations with potentials for anaerobic function. Journal of Comparative Physiology, 143, 191-198.

Davey, C. L. (1960). The significance of carnosine and anserine in striated skeletal muscle. Archives of Biochemistry and Biophysics, 89, 303-308.

Fernandez, X. \& Tornberg, E. (1991). A review of the causes of variation in muscle glycogen content and ultimate pH in pigs. Journal of Muscle Foods, 2, 209-235.

Fernandez, X., Tornberg, E., Naveau, J., Talmant, A. \& Monin, G. (1992). Bimodal distribution of the muscle glycolytic potential in French and Swedish populations of Hampshire crossbred pigs. Journal of Science in Food and Agriculture, 59, 307-311.

Guignot, F., Quilichini, Y., Renerre, M., Lacourt, A. \& Monin, G. (1992). Relationships between muscle type and some traits influencing veal colour. Journal of Science in Food and Agriculture, 58, 523-529.

Hamm, R. (1972). Kolloidchemie des Fleisches. 222 p. Berlin and Hamburg: Paul Parey. Hamm, R. (1977). Postmortem breakdown of ATP and glycogen in ground muscle: A review. Meat Science, 1, 15-39. 
Henckel, P., Jörgensen, P. F. \& Jensen, P. (1992). Glycogen content, buffering capacity and resting $\mathrm{pH}$ in live muscles of pigs of different halotane genotypes (a pilot project). Meat Science, 32, 131-138.

Henckel, P., Karlsson, A., Jensen, M. T., Oksbjerg, N. \& Petersen, J. S. (2002). Metabolic conditions in porcine longissimus muscle immediately pre-slaughter and its influence on peri- and post mortem energy metabolism. Meat Science, 62, 145-155.

Hill, A. R., Irvine, D. M. \& Bullock, D. H. (1985). Buffer capacity of cheese wheys. Journal of Food Science, 50, 733-738.

Honikel, K. O. \& Hamm, R. (1974). Uber das pufferungsvermögen des fleisches und seine veränderungen post mortem. Zeitschrift für Lebensmittel - Untersuchung und - Forschung, $156,145-152$

Juel, C. (1997). Lactate-proton cotransport in skeletal muscle. Physiologica Reviews, 77, 321358.

Kastenschmidt, L. L., Hoekstra, W. G. \& Briskey, E. J. (1968). Glycolytic intermediate and co-factors in "fast- and slow-glycolyzing" muscles of the pig. Journal of Food Science, 33, 151-158.

Kauffman, R. G., Sybesma, W., Smulders, F. J. M., Eikelonboom, G., Engel, B., van Laack, R. L. J. M., Hoving-Bolink, A. H., Sterrenburg, P., Nordheim, E. V., Walstra, P. \& van der Wal, P. G. (1993). The effectiveness of examining early postmortem musculature to predict ultimate pork quality. Meat Science, 34, 283-300.

Kivikari, R. (1996). Buffering Capacity of Meat. EKT-series 1203. Academic dissertation, Department of Food Technology, University of Helsinki. Helsinki: University Press. Livingston, D. J. \& Brown, W. D. (1981). The chemistry of myoglobin and its reactions. Food Technology, 35(5), 244-252. 
Lundström, K., Essén-Gustavsson, B., Rundgren, M., Edfors-Lilja, I. \& Malmfors, G. (1989). Effect of halotane genotype on muscle metabolism at slaughter and its relationship with meat quality: A within-litter comparison. Meat Science, 25, 251-263.

Merkel, R. A. (1971). The relationship of some cardiovascular and haematological parameters to porcine muscle quality. In: Proceedings $2^{\text {nd }}$ International Symposium on Condition and Meat Quality of Pigs (pp. 97-103). Pudoc, Wageningen, The Netherlands.

Monin, G. \& Sellier, P. (1985). Pork of low technological quality with a normal rate of muscle $\mathrm{pH}$ fall in the immediate post-mortem period: The case of the Hampshire breed. Meat Science, 13, 49-63.

Monin, G., Mejenes-Quijano, A., Talmant, A. (1987). Influence of breed and muscle metabolic type on muscle glycolytic potential and meat pH in pigs. Meat Science, 20, 149158.

Morita, S., Cassens, R. G., Briskey, E. J., Kauffman, R. G. \& Kastenschmidt, L. L. (1970). Localization of myoglobin in pig muscle. Journal of Food Science, 35, 111-112.

Offer, G. \& Knight, P. (1988). The structural basis of water-holding in meat. Part 2: Drip losses. In R. Lawrie, Developments in Meat Science (Vol. 4, pp. 173-243). Cambridge: University Press.

Okuma. E. \& Abe, H. (1992). Major buffering constituents in animal muscle. Comparative Biochemistry and Physiology, 102A(1), 37-41.

Olsman, W. J. \& Slump, P. (1981). Methods of determination of connective tissue free muscle protein in meat products. In R. Lawrie, Developments of meat science 2 (pp. 195-240). London: Applied Science Publishers.

Phasta System $^{\mathrm{TM}}$, (1989). Owners Manual. Pharmacia (Laboratory Separation Division). Pharmacia LKB Biotechnology. Sweden.

Puolanne, E. \& Kivikari, R. (2000). Determination of the buffering capacity of postrigor meat. Meat Science, 56, 7-13. 
Rao, M. V. \& Gault, N. F. S. (1989). The influence of fiber type composition and associated biochemical characteristics on the acid buffering capacities of several beef muscles. Meat Science, 26, 5-18.

Renou, J.-P., Canioni, P., Gatelier, P., Valin, C. \& Cozzone, P. J. (1986). Phosphorus-31 nuclear magnetic resonance study of post mortem catabolism and intracellular $\mathrm{pH}$ in intact excised rabbit muscle. Biochimie, 68, 543-554.

Roos, A. \& Boron, W.F. (1981). Intracellular pH. Physiological reviews, 61(2), 296-434.

Ruusunen, M. \& Puolanne, E. (2003). The relationship between the physiological capacity, and meat quality and animal welfare in pigs. Study report, Makera project 4013/501/99. University of Helsinki, Department of Food Technology. In Finnish.

SAS Institute Inc. (1990). SAS/STAT User’s Guide. Version 6. Fourth edition, Vol. 2. Gary, NC, USA. 846 p.

Sayre, R. N., Briskey, E. J., Hoekstra, W. G. (1963). Comparison of muscle characteristics and post-mortem glycolysis in three breeds of swine. J. Animal Sci. 22, 1012-1020.

Sepponen, K., Koho, N., Puolanne, E., Ruusunen, M. \& Pösö, A. R. (2003). Distribution of monocarboxylate transporter isoforms MCT1, MCT2 and MCT4 in porcine muscle. Acta Physiologica Scandinavica, 177, 79-86.

Somero, G. N. (1986). Protons, osmolytes, and fitness of internal milieu for protein function. American Journal of Physiology, 251, R197-R213.

Talmant, A., Monin, G., Briand, M., Dadet, M. \& Briand, Y. (1986). Activites of metabolic and contractile enzymes in 18 bovine muscles. Meat Science, 18, 23-40.

Tarrant, P. J. V., McLoughlin, J. V. \& Harrington, M. G. (1972). Anaerobic glycolysis in biopsy and post-mortem porcine longissimus dorsi muscle. Proceedings of the Royal Irish Academy, 72B, 55-73. 
Trout, G. R. (1991). A rapid method for measuring pigment concentration in porcine and other low pigmented muscles. In Proceedings $37^{\text {th }}$ International Congress of Meat Science and Technology (pp.1198-1201), Kulmbach, Germany.

Van Laack, R. L. J. M. \& Kauffman, R. G. (1999). Glycolytic potential of red, soft, exudative pork longissimus muscle. Journal of Animal Science, 77, 2971-2973.

Van Laack, R. L. J. M., Kauffman, R. G. \& Greaser, M. L. (2001). Determinants of ultimate pH of meat. Proceedings $47^{\text {th }}$ International Congress of Meat Science and Technology (pp. 22-26). Krakow, Poland.

Van Laack, R. L. J. M., van Liu C.-H., Smith, M. O. \& Loveday, H. D. (2000). Characteristics of pale, Soft, exudative broiler breast meat. Poultry Science, 79, 1057-1061.

Warner, R. D., Kauffman, R. G. \& Russell, R. L. (1993). Quality attributes of major porcine muscles: A comparison with the longissimus lumborum. Meat Science, 33, 359-372. 
Legend to the figure

Figures 1 (a)-(e). The pH at ST1 of light gluteus, longissimus dorsi, semimembranosus muscles and dark infraspinatus and masseter muscles in relation to lactate content. N.B. The x-axis of light muscles is to $120 \mathrm{mmol} / \mathrm{kg}$ and of dark muscles to $60 \mathrm{mmol} / \mathrm{kg}$. 
Table 1. LSMeans and standard deviations of $\mathrm{pH}_{\mathrm{ST} 1}$, the lactate concentration at first sampling, $\mathrm{pH}_{\mathrm{ST2}}$, the lactate concentration at second sampling and BC in different porcine muscles.

\begin{tabular}{|c|c|c|c|c|c|}
\hline & $\mathrm{pH}_{\mathrm{ST} 1}$ & $\begin{array}{l}\text { Lactate }_{\mathrm{ST} 1} \\
\mathrm{mmol} / \mathrm{kg}\end{array}$ & $\mathrm{pH}_{\mathrm{ST} 2}$ & $\begin{array}{l}\text { Lactate }_{\mathrm{ST} 2} \\
\mathrm{mmol} / \mathrm{kg}\end{array}$ & $\begin{array}{l}\mathrm{BC} \\
\mathrm{mmol} \\
\mathrm{LA} /\left(\mathrm{pH}^{*} \mathrm{~kg}\right)\end{array}$ \\
\hline gluteus superficialis & $\begin{array}{l}6.46 \pm .20 a b \\
n=36\end{array}$ & $\begin{array}{l}53.2 \pm 14.7 a \\
n=36\end{array}$ & $\begin{array}{l}5.48 \pm .08 a \\
n=36\end{array}$ & $\begin{array}{l}101.4 \pm 6.4 a \\
n=36\end{array}$ & $\begin{array}{l}48.3 \pm 8.8 a \\
n=36\end{array}$ \\
\hline longissimus dorsi & $\begin{array}{l}6.43 \pm .22 \mathrm{ab} \\
\mathrm{n}=36\end{array}$ & $\begin{array}{l}56.3 \pm 14.3 a b \\
n=36\end{array}$ & $\begin{array}{l}5.45 \pm .06 a \\
n=36\end{array}$ & $\begin{array}{l}104.6 \pm 7.7 a \\
n=36\end{array}$ & $\begin{array}{l}48.6 \pm 9.2 a \\
n=36\end{array}$ \\
\hline semimembranosus & $\begin{array}{l}6.37 \pm .28 a \\
n=36\end{array}$ & $\begin{array}{l}61.9 \pm 15.0 \mathrm{~b} \\
\mathrm{n}=36\end{array}$ & $\begin{array}{l}5.46 \pm .09 a \\
n=34\end{array}$ & $\begin{array}{l}104.9 \pm 8.3 a \\
n=34\end{array}$ & $\begin{array}{l}46.8 \pm 13.0 a \\
n=34\end{array}$ \\
\hline infraspinatus & $\begin{array}{l}6.48 \pm .12 \mathrm{ab} \\
\mathrm{n}=35\end{array}$ & $\begin{array}{l}36.7 \pm 8.5 c \\
n=35\end{array}$ & $\begin{array}{l}5.89 \pm .16 b \\
n=14\end{array}$ & $\begin{array}{l}66.1 \pm 9.2 b \\
n=14\end{array}$ & $\begin{array}{l}45.3 \pm 13.1 a b \\
n=13\end{array}$ \\
\hline masseter & $\begin{array}{l}6.53 \pm .11 b \\
n=36\end{array}$ & $\begin{array}{l}31.7 \pm 5.5 c \\
n=36\end{array}$ & $\begin{array}{l}5.95 \pm .07 b \\
n=16\end{array}$ & $\begin{array}{l}55.6 \pm 3.7 \mathrm{c} \\
\mathrm{n}=16\end{array}$ & $\begin{array}{l}32.0 \pm 11.5 c \\
n=16\end{array}$ \\
\hline significance & $* *$ & $\mathrm{a} \& \mathrm{~b}^{*} \mathrm{a} \& \mathrm{c}, \mathrm{b} \& \mathrm{c} * * *$ & $* * *$ & $* * *$ & $\mathrm{a} \& \mathrm{c} * * * \mathrm{~b} \& \mathrm{c} *$ \\
\hline
\end{tabular}
Means in columns with the same superscript are not significantly different at the $5 \%$ level $* * * \mathrm{p}<.001, * * \mathrm{p}<0.01, * \mathrm{p}<.05$ 